Send your letters to the editor, British Dental Journal, 64 Wimpole Street, London W1G 8YS E-mailbdj@bda.org

Priority will be given to letters less than 500 words long. Authors must sign the letter,

which may be edited for reasons of space

\section{Support for smokers}

Sir, I would like to add two points to the interesting article by Dr R.A. Baker on smoking cessation for patients with mental and behavioural disorders ( $B D J$ 2005; 198: 529-531). Firstly, I believe that he has incorrectly referenced the recent report from the Health Development Agency - Helping smokers stop: A guide for the dental team. Its authors were Dr R.H. Beaglehole and Dr R.G. Watt, rather than Watt and Robinson (who wrote the previous version published by the Health Education Authority in 1999). Readers who wish to brief themselves on this subject should ensure that they use the up to date 2004 report, as it outlines a 'modified 4 As' approach for the dental team to use, highlighting the importance of appropriate referral of smokers to specialist smoking cessation services. Secondly, the Health Development Agency also published a report in 2004 by Dr A. McNeill, Smoking and patients with mental health problems. This concludes that many smokers with mental health problems want to stop smoking, but do not receive the advice and support they need to do so, and that good evidence exists that smokers with mental health problems can be helped to stop smoking. It also puts forward a number of practical recommendations, relating for example to the close monitoring of quit attempts by smokers on psychotropic medication, to check whether there is any exacerbation of medication side-effects, whether the dose of neuroleptic medication needs to be altered, or if the smoker needs further help with withdrawal symptoms and urges to smoke. Though the Health Development Agency has now been abolished as a separate agency, both reports are available to download as PDFs from www.hda-online.org.uk

\section{Stillman-Lowe}

Twyford

doi: 10.1038/sj.bdj.4812752

\section{Dentist versus doctor}

Sir, St George et al. (BDJ 2005; 198: 341) and Brown (BDJ 2005; 198: 731) described two cases of missed diagnosis of malignancies by a dental technician and a dental practitioner, respectively, and stated that general medical practitioners have been shown to be better at diagnosis and prompt referral of oral malignancies than their dental colleagues.

This may be the truth according to one report. ${ }^{1}$ However, other large-scale research has revealed no significant difference in professional delay of oral malignancies between dentists and physicians, ${ }^{2-6}$ whereas other publications conclude that dentists refer patients at earlier stages than physicians do. ${ }^{7-11}$ According to Holmes et al., ${ }^{11}$ oral- or oropharyngeal-squamous cell carcinoma (SCC) patients referred from dental offices were of significantly lower stage (TMN 1.94) than those referred from medical offices (TMN 3.00). As many as 72\% of patients referred by physicians and ENT specialists were of advanced stages and only $21 \%$ of the patients referred by dentist and dental hygienists. ${ }^{11}$ Recently, Gordon et al. ${ }^{13}$ reported a case of misdiagnosis of tongue SCC as an apthous ulcer and later as an oral candidiasis by a dermatologist.

Although more attention and education among dentists is needed, still the dental profession is the only profession capable and dedicated to the diagnosis and treatment of diseases of the oral cavity. Y. Zadik

\section{Israel}

doi: 10.1038/sj.bdj.4812753

1. Schnetler J F. Oral cancer diagnosis and delays in referral. Br J OralMaxillofac Surg 1992; 30: 210-213.

2. Scully C, Malamos D, Levers B G, Porter S R, Prime SS. Sources and patterns of referrals of oral cancer: role of general practitioners. Br Med J 1986; 293: 599-601.

3. Dimitroulis G, Reade P, Wiesenfeld D. Referral patterns of patients with oral squamous cell carcinoma, Australia. Eur J Cancer B Oral Oncol 1992; 28B: 23-27.

4. Jovanovic A, Kostense P J, Schulten E A, Snow G B van der Waal I. Delay in diagnosis of oral squamous cell carcinoma; a report from The

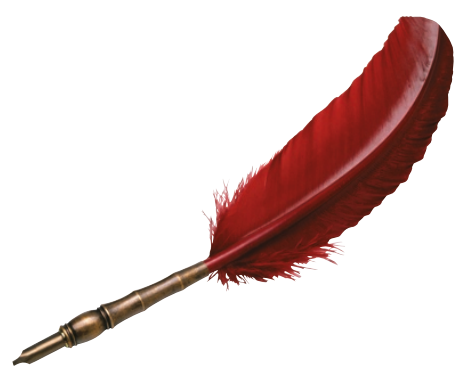

Netherlands. Eur J Cancer B Oral Oncol 1992; 28B: 37-38.

5. Kerdpon D, Sriplung H. Factors related to delay in diagnosis of oral squamous cell carcinoma in southern Thailand. Oral Oncol 2001; 37: 127-131.

6. Onizawa K, Nishihara K, Yamagata K, Yusa H, Yanagawa T, Yoshida H. Factors associated with diagnostic delay of oral squamous cell carcinoma. Oral Oncol 2003; 39: 781-788.

7. Cooke B E, Tapper-Jones L. Recognition of oral cancer. Causes of delay. Br DentJ 1977; 142: 96-98.

8. Amsel Z, Strawitz J G, Engstrom P F. The dentist as a referral source of first episode head and neck cancer patients. J Am Dent Assoc 1983; 106: 195-197.

9. Kowalski LP, Franco E L, Torloni H, Fava AS, de Andrade Sobrinho J, Ramos G, Oliveira B V, Curado M $P$. Lateness of diagnosis of oral and oropharyngeal carcinoma: factors related to the tumour, the patient and health professionals. Eur J Cancer B Oral Oncol 1994; 30B: 167-173.

10. Gorsky M, Dayan D. Referral delay in diagnosis of oro/oropharyngeal cancer in Israel. Eur J Cancer B Oral Oncol 1995; 31B: 166-168.

11. Holmes J D, Dierks E J, Homer L D, Potter B E. Is detection of oral and oropharyngeal squamous cancer by a dental health care provider associated with a lower stage at diagnosis? J Oral Maxillofac Surg 2003; 61: 285-291.

13. Gordon M, Rishpon S, Gorski M. Delayed diagnosis of carcinoma of the oral cavity. J Isr Med Assoc 2005; 144: 243-245. (Hebrew.)

\section{Damage limitation}

Sir, I read with fascination Drs Whitton and Brennan's article on tissue damage following extravasation of sodium hypochlorite during endodontic treatment (BDJ 2005; 198: 749).

It is unfortunate that the report does not include details of the type of syringe used for irrigation in this case. It is my opinion that extraradicular damage can be nearly completely prevented by using a dedicated endodontic syringe with a needle that has a cut away end, such as the Monojet 3cc Endo Syringe.

With this type of needle it is impossible to irrigate deeper than the depth of the needle. As long as the end of the 27 gauge needle is not jammed into the apex of the canal and there are no perforations present, irrigation with full strength hypochlorite is perfectly safe.

\section{Austin}

Brighton

doi: 10.1038/sj.bdj.4812754 